\title{
Brazilian industry and knowledge absorption: internal and external company determinants ${ }^{1}$
}

\author{
Philipe Scherrer Mendes, Gustavo Britto \\ and Ana Maria Hermeto
}

\begin{abstract}
Technological composition and productive diversification are distinguishing features of countries' long-term growth trajectories. Investing in research and development (R\&D), infrastructure and technology is a possible alternative for developing countries looking to accelerate their growth trajectory. In the case of Brazil, the production structure must be modified and productivity increased, by endogenizing technological advances, in order to narrow the technology gap. The factors that determine investment in absorption of external knowledge must be defined. To this end, a multilevel analysis was performed, based on microdata from the local unit section of the Annual Industrial Survey-Enterprise (Pesquisa Industrial Anual-Unidade Local) and the Survey of Innovation (PINTEC) (2008, 2011 and 2014) conducted by the Brazilian Institute of Geography and Statistics (IBGE). The results bear out the theory regarding the internal determinants of firms' innovative activities. Municipal determinants appear consistent with the literature only for "machinery and equipment" and "training" expenditure, while diversified spaces have little influence on levels of R\&D expenditure.
\end{abstract}

\section{Keywords}

Industry, industrial enterprises, investments, technological innovations, know-how, technological change, industrial development, Brazil

\section{JEL classification}

O14, R11

\section{Authors}

Philipe Scherrer Mendes has a doctorate in Economics from the Federal University of Minas Gerais, Brazil. Email: philipescherrer@gmail.com.

Gustavo Britto is an Associate Professor in the Department of Economics of the Federal University of Minas Gerais. Email: gustavo@cedeplar.ufmg.br.

Ana Maria Hermeto is an Associate Professor in the Department of Economics of the Federal University of Minas Gerais. Email: ahermeto@cedeplar.ufmg.br.

1 The authors would like to thank the Brazilian Institute of Geography and Statistics (IBGE) for providing access to the microdata and the Institute of Applied Economic Research (IPEA) for assistance in the IBGE confidential data room. Financial support from the Brazilian National Research Council (CNPq) and the Research Foundation of Minas Gerais (FAPEMIG) is gratefully acknowledged. 


\section{Introduction}

One of the central aspects of economic development relates to the process of innovation, which according to Schumpeter (1982) is the only phenomenon capable of increasing the wealth of an economy in the long term. In the discussion on the processes that lead to innovation, the production, adoption and diffusion of technological innovation are identified as essential factors for economic growth and social change. Technological innovation is also a distinctive feature of countries' products and sectors that compete successfully in the global market.

Countries with more diverse, high-tech production tend to differ from countries whose production structure is based on products with limited processing or technological content, which compete on price. This difference has been alluded to as a reason for structural imbalances in developing countries' balance of trade, as a result of the uneven generation and diffusion of technological progress (Kaldor, 1957; Thirlwall, 1979; McCombie and Thirlwall, 1994, among others). The technological gap among countries has created severe problems in terms of international competitiveness, whereby growth in exports from developing countries (which manufacture low-tech products) is intrinsically linked to trends in international demand.

Industrialized countries aim to create conditions that will enable them to stay at the forefront of technological progress, reducing the vulnerability of their import and export structures by exporting products with higher income elasticity and reducing imports of such products. Industrialization alone does not seem able to reduce the vulnerability of economies to external constraints (Tavares, 2016). This is why the technological frontier and the endogenization of ongoing processes of progress and innovation are important. Fajnzylber (1990) states that underdeveloped economies have been unable to open the "black box" of technical progress and do not have the right conditions to increase their output and productivity.

Innovation in peripheral countries has a number of features that distinguish it from innovation in countries with developed industries. Viewing economic development as a historical process, it is important to consider the socioeconomic elements of the structure of developing countries based on the idea that development consists "of the transplantation of an advanced technology into a backward economy which is unable to produce it endogenously, as the outcome of its own evolutionary processes" (Merhav, 1969). In that regard, investing in knowledge acquisition can be an alternative means of achieving growth. However, this acquisition should not be understood as a mere purchase. For there to be real opportunities for knowledge acquisition, companies must invest in the capacity to absorb knowledge internally. This capacity appears to be a key factor in differentiating companies. Cohen and Levinthal (1990) define absorptive capacity as the ability to "recognize the value of new, external information, assimilate it, and apply it to commercial ends", and they underscore the importance of prior related knowledge. It would seem that external sources are critical to the innovation process, and the ability to explore the aforementioned knowledge, evaluate it and use it is crucial to a firm's ability to innovate.

Having identified the industrial sector as capable of being a generator of more growth and having connected the possible outcomes of these investments in terms of productivity and growth, it is possible to draw a parallel between firms' innovation aims, namely profits and market share, and the eventual outcome of this process, in terms of greater industrial productivity and the importance of this growth for the economy's overall performance. In that respect, the purpose of this study is to measure, within the Brazilian process industry, the determinants of Brazilian industrial 'firms' investment in absorptive capacity, controlling for the territory's influence.

This analysis contributes to the literature by jointly analysing internal and external determinants of firms' investment decisions regarding knowledge absorption. The importance of this analysis and its results and conclusions are strengthened by the level of disaggregation of the data, the representativeness 
of the two databases used - the Annual Industrial Survey (Pesquisa Industrial Anual, PIA) and the Survey of Innovation (Pesquisa de Inovação, PINTEC) overseen by the Brazilian Institute of Geography and Statistics (IBGE) - and the controls for spatial heterogeneity using indicators of the formal labour market, especially in view of the size of Brazil's territory and the differences within the country. ${ }^{2}$ This study also seeks to contribute to the subject by differentiating between two types of investment in knowledge acquisition that may generate innovation and which are interrelated in different ways with territorial characteristics.

\section{Theoretical aspects of technological absorptive capacity}

\section{The importance of developing these capacities}

Students of the processes that lead to innovation recognize that the production, adoption and diffusion of technological innovation are essential for economic development and social change (Malerba, 1992; Teece and Pisano, 1994; Bell and Pavitt, 1997, among others) and that technological innovation is a distinctive feature of high-income countries' products and sectors that compete successfully in the global market. Therefore, the magnitude of a company's (micro) absorptive capacity is intertwined with the profile of its industry (meso) and the wealth-generating capacity of the country (macro). Hence why this literature is important for understanding development as a whole.

Innovative activities, such as those described below, play an important role in building technological capabilities by enabling a better understanding of where the market is heading and optimizing investments for the opportunities that are created. Malerba (1992) affirms that firms' technological activities are responsible for generating knowledge that is fundamental in the processes of learning by doing, using, searching and interacting, among other actions. Adopting a similar perspective, Bell and Pavitt (1997) highlight the importance of building capacities to generate and manage technical change, in particular the development of productive skills and accumulation of knowledge and experience.

The decisions that determine a company's path and its accumulated knowledge and skills lead to the development of an almost inimitable set of capabilities, which are drawn on to carry out its activities (Teece and Pisano, 1994). The challenge, however, is to create conditions that are conducive to investment in knowledge and innovative activities that will yield the expected results when approaching or upon reaching the technological frontier. While this problem is faced by firms that are established in developed countries, the situation is even more complex in late industrializing countries. The fact that accumulation is part of the process of technological progress gives companies that are at the technological frontier advantages over those that lag behind. It is precisely the pursuit of this differentiating advantage that drives technological progress.

The speed of technological progress depends on a number of factors and a minimum level of capabilities must exist within a company to prevent it from being pushed out of the market. ${ }^{3}$ Regardless of considerations relating to the pace of growth in each sector, companies must be well versed in their operating environments, so that, at the very least, they do not drift away from the production frontier to the point of being pushed out of the market. If the company does not grow fast enough or accumulate sufficient knowledge to set the rules that shape a sector, it must at least have the capacity to understand the sector's characteristics, in order to remain in the market.

\footnotetext{
2 According to the Annual Social Information Report (RAIS) of the Ministry of Economic Affairs (2019).

3 Factors such as technological opportunities or technological paradigms.
} 
Cohen and Levinthal (1990) coined the term "absorptive capacity" and defined it as the ability to recognize the value of new, external information, assimilate it, and apply it to commercial ends, which is largely a function of a firm's level of prior related knowledge. External sources are critical to the innovation process, and the ability to exploit outside knowledge is a crucial part of a firm's ability to innovate.

When examining the interaction between universities and firms, Meyer-Krahmer and Schmoch (1998) highlight the importance of developing absorptive capacity, since this allows firms to recognize and adopt new technological paradigms. Van den Bosh, Volberda and de Boer (1999) state that companies must build knowledge absorption capacity, because it enables them to speed up technological advances and can differentiate them from competitors. Capabilities that allow companies to integrate, build and reconfigure competences to address rapidly changing environments or paradigms are fundamental to their performance (Teece, Pisano and Shuen, 1997). According to Zahra and George (2002), absorptive capacity should be understood as a set of organizational routines and processes that create favourable conditions for production advances. This also enables companies to build skills and capabilities to cope with changes and restructure their activities, enabling them to gain and maintain competitive advantages. Historically, companies that have invested more in absorptive capacity have increased their chances of seizing greater opportunities.

As a form of learning, absorptive capacity differs from learning by doing in that it is not an automatic process through which one acquires ever greater practical experience and efficiency in the same activity. Although firms have different means of accumulating knowledge (learning processes), the generation of stocks of knowledge and technological capabilities yields enhancements in trajectories of technological advance, not just production cost reductions (Malerba, 1992). It is a costly process, and one that requires effort and discipline, but it generates technological advantages for companies by creating the right conditions for the internalization of knowledge. However, it cannot be created overnight or with simple, short-term solutions.

Regarding the search for ways to optimize construction of knowledge absorption capacity, Cohen and Levinthal (1989) find a strong parallel between this capacity and investment in research and development (R\&D). Companies not only invest in $R \& D$ to seek new processes or products directly, but also to develop and expand their capabilities to assimilate and exploit externally available information. Thus, the incentive for absorption through spillovers is seemingly greater in sectors where learning hurdles are greater. In addition, the learning environment affects the impact of spillovers on R\&D expenditure, and the importance of expanding absorptive capacity - in relation to negative appropriability conditions - is determined by the degree of interdependence among competitors.

Identifying the determinants of capability building is fundamental to optimizing paths and creating conditions that minimize the technology gap. This is the challenge that must be addressed by late industrializing economies, on the understanding that industrial progress is a determinant of a country's economic growth, based on more productive companies, improved processes, more complex output and greater income elasticity of products. This allows firms to secure a better position in international markets and, through aggregate demand, higher income levels, faster production growth and increasing levels of productivity and, consequently, of remuneration for work.

The acquisition of external technologies and knowledge facilitates - but does not guaranteeimproved technological performance by the importing country. In this regard, while it is possible for the least developed nations to expand their technological frontiers with respect to advanced nations, a minimum capacity is needed to enable effective absorption and use of the knowledge acquired. Therefore, ongoing technological training must be provided to expand the technological capabilities that allow better use to be made of imported technologies (Chiarini, 2014).

Technological innovation should be understood as a learning process in which innovations are not necessarily radical, but rather one where small incremental innovations may contribute to increasing the productivity of a firm or a country (Rosenberg, 1983). Abramovitz (1986) describes learning that is 
made possible by a differential among countries' stages of technological development, in which the performance of follower countries depends on their initial circumstances. The development of "social capabilities" appears to be crucial to creating the right conditions for identifying and absorbing existing know-how, which when appropriated by followers should increase their productivity. These "social capabilities" are technical competences that cannot be understood without taking into account other important actors or institutions of a political, commercial, industrial and financial nature, among others, in addition to considering educational levels and the organizational and institutional frameworks in which enterprises exist. Abramovitz (1986) considers that the combination of the technological gap and "social capability" defines a country's potentiality to stimulate its catch-up process, improving productivity. For that to happen, there must be channels to promote flows of knowledge from leaders to followers.

Some late industrializing economies went from being technologically backward and poor to being relatively modern and affluent by assembling a significant collection of industrial firms that produce technologically complex products and compete effectively against firms based in industrially advanced countries (Kim and Nelson, 2000). The acquisition and progressive control of new technologies has been a key feature of the late industrializing economies that grew rapidly after the 1980s. In addition to substantial investment in physical and human capital, it was crucial that some countries that were considered imitators in the 1960s acquired and assimilated technologies that existed in advanced economies. Together, these two factors transformed those countries into innovators in the 1990s. However, this is not a simple process or one with a quick return. The fact that technological know-how is not evenly distributed among firms and cannot be easily imitated or transferred among them means that transfers require significant absorptive capacity, as the underlying principles are not easily assimilated.

Within the developmentalist-industrial paradigm, in order to surmount underdevelopment, technological dependence must be overcome and conditions created that favour endogenizing technological development, even if foreign practices have to be adopted to accelerate the process. Adopting foreign techniques or importing technology should not be seen as an end, but as an opportunity to create the internal conditions for the future development of new forms of production or new products. Caution should be exercised when importing technology, as it can result in underdeveloped economies remaining caught in the technological dependence trap. Readily available technologies tend to be mature technologies whose technological growth has been exhausted. However such technologies may be superior to the domestic technology of the country, moving it further away from the technological frontier and helping to maintain the technological distance between advanced and less advanced countries (Chiarini, 2014).

An important aspect to be considered in this debate is that the conditions for the dissemination and absorption of knowledge are geographically limited. This study therefore also attempts to explain how companies' locations are linked to creating the conditions for knowledge absorption. The next section addresses the debate on the dynamics of technological progress from a regional perspective, presenting and discussing the territorial features that drive innovation and production.

\section{Territorial determinants}

The literature on economies of agglomeration describes the relationship between industrial growth and firms' productivity, derived from external economies of scale, as determined by the region's productive structure. Geographical proximity, which is fundamental in determining the level of innovative activity and technological progress, enables companies to exchange information and make technological progress. This helps to mitigate uncertainty, an inherent feature of innovative activity (Feldman, 1994), and to create a productive externality that reduces the cost of new discoveries. Thus, technological spillovers tend to be concentrated in space, hence productive clustering in an effort to benefit from them. Broadly speaking, two different lines of theory can be distinguished within this debate. Although the 
considerations behind these two currents are not mutually exclusive, there is a clear distinction between Marshall (1890) and Jacobs (1969). According to Marshall (1890), these externalities come from the specialization of industrial activity and can be summarized as follows: effects of intersectoral-supplier-user linkages, technological spillovers of knowledge among firms and benefits from creating specialized hubs. Meanwhile, Jacobs (1969) states that the main source of beneficial externalities for companies is the diversity of economic activities carried out in cities. The multiplicity of goods and services, technologies and knowledge characteristic of a diversified urban area enhances the cross-fertilization of ideas (Glaeser and others, 1992). In other words, innovations originate from the cross-fertilization of ideas among the various sectors of activity in the same city, which are driven by the generation of new types of work, increasing the capacity to generate new goods and services.

The advantages of urban agglomeration are not limited to the area of production. Large cities offer a greater variety of consumer goods and public services and greater possibilities for social contact, which should translate into externalities. Thus, they are also attractive to workers and consumers. The arrangement of productive activities in the space is also influenced by dispersive forces. However, these forces should not be understood as the absence or non-existence of agglomerative forces. In other words, the benefits of urban agglomeration are valid for all actors in the production process even while dispersive forces act. Nevertheless, only actors who overcome the difficulties arising from centrifugal forces tend to occupy the best positions or central locations. The main dispersive factor is related to land income or urban land income, which is derived from the existence of property rights. This results in a need for a consideration in exchange for use of a site (rent per unit of floor area) and tends to differentiate rental values according to location and proximity to the consumer market (Von Thünen, 1966). The tendency towards high prices in central locations and lower prices further from the centre determines the type of activity that is typically located in each place. The ability to pay this rent differential is linked to the profitability of an activity, meaning that only the most profitable (profit per unit of floor area) activities have access to the central spaces. Hence, the localization of production is determined by a productivity gradient, which generates a spatial hierarchy, and income from urban land applies a dispersive force, because it pushes out those who cannot afford to establish themselves in privileged locations.

Glaeser and others (1992) suggest that technological spillovers occur between companies in the same industry and positively affect growth. They argue that industrial specialization facilitates access to inputs, intermediate goods and services, labour and markets. Advocates of the existence of an externality derived from industrial specialization gained prominence in regional economic theory and have carried out various empirical studies to assess the extent to which this theory reflects reality (Glaeser and others, 1992; Combes, 2000; Henderson, 2003, among others). Despite the empirical evidence, provided in several works, it is well-known that there are cities or regions with significant economic growth that are not specialized spaces. Regarding this lacuna, Jacobs (1969) gives another important characterization of space as a factor that generates dynamism. Without refuting the productive efficiency gained through specialization, Jacobs (1969) considers that the possibilities created by specialized spaces are relatively limited compared to those created in diversified spaces. She states that production diversification is largely responsible for the flowering of new ideas and knowledge. Accordingly, although the importance that Jacobs (1969) attaches to the region and to face-to-face contact is similar to that of Marshall (1890), in her work the possibility of complementarity or cross-fertilization of different information and technologies in various sectors is considered to be primarily responsible for the emergence of greater economic dynamism. Thus, regions with a wide variety of productive sectors would have a better chance of innovating, especially owing to the possibilities created by exchanging and recombining knowledge and practices (Jacobs, 1969).

As suggested by Duranton and Puga (2000), diversification and specialization can coexist, with a tendency for large cities, and the activities within them, to become more diversified and stable in terms of size. While most innovations tend to occur in diversified cities, where most new production plants are also based, specialized cities are the main destination for companies relocating from diversified cities. 
On this last point, the argument is that once companies find their ideal production process, they do not necessarily have other incentives to stay in diversified cities, so they offset high production costs with location-related benefits and tend to move to where other companies share their specialization.

The constant search for new products and market niches fostered geographical dispersion of production, breaking away from the productive rigidity of the Fordist period to seek greater flexibility in labour markets, with new forms of supplying inputs and services that required a number of transformations in organizational and commercial patterns. According to Ernst and Kim (2002), what they call "global network flagships" will play a central role in this new model, by maximizing the use of globally dispersed resources and accessing competencies located in different places, which complement each other to improve productive efficiency. While productive activity was spreading throughout territories, new forms of territorial centralization emerged, generally related to high-level management and central control of operations. To some degree, these movements show reorganization, driven by dispersive factors related to the cost of localization. In this context, the most labour-intensive companies tend to relocate first (Puga and Venables, 1996), affected by increases in wages in developed regions, leading to the formation of new centres of activity, which possess the critical mass for production.

Technological advances have reduced the cost of spreading out productive activity, creating a strong incentive for cities to shift their specialization from a sectoral dimension to one that is function-based. As a large number of companies make the same choice, it comes to define the employment pattern in cities and gives rise to industrial cities and cities that are home to companies' core activities. ${ }^{4}$ This new division brings greater benefits of proximity to core activities than to productive activities. This reflection in turn leads to the observation that cities that are home to firms' core activities are much larger and fewer in number, while industrial cities are smaller in size and more numerous (Duranton and Puga, 2000).

Barbour and Markusen (2007) state that innovative and developmental activities tend to be anchored in a company's region of origin, while more routine production and service functions are dispersed to lower-cost and downstream-consuming locations. They stress the importance of occupational analysis over industrial analysis, and affirm that, with this new industrial structure, companies in the same sector may present completely different occupational structures in different locations, which would be a determining factor in productivity growth and regional performance.

\section{Peculiarities of Brazil}

Turning this discussion to Brazil, a late industrializing country with significant spatial heterogeneity, there are certain territorial characteristics that favour dissemination of technological know-how to different degrees. ${ }^{5}$ The lack of a minimum social capability that allows knowledge to be absorbed (Abramovitz, 1986) excludes a large portion of Brazil's territory from productive and industrial progress. However, the country clearly underwent a reorganization of its productive structure and spatial distribution following the 1990s. This restructuring, which was closely linked to the external market and higher demand for skilled labour, became more influenced by location factors. In that context, urbanization emerged more clearly as a key element of the new productive restructuring dynamic. As part of this process, new studies on economies of agglomeration, which link external economies of scale and the regional production structure to productivity levels, have recently begun to play a more prominent role (Galinari, Lemos and Amaral, 2006; Fontes, Simões and Oliveira, 2010; Freitas, 2012).

The economic growth and income distribution seen in Brazil in the 2000s was largely influenced by external demand for commodities, which allowed for an uptick in domestic labour market participation

\footnotetext{
4 Company headquarters, which include activities such as management, commercial services and R\&D hubs.

5 The Brazilian production and industrial structure is largely concentrated in the state of São Paulo and in the South-East region, despite recent policies that encouraged regional redistribution of industry, especially into the North-East region.
} 
and income. The international crisis of 2008 seems to have changed the course of history somewhat: this process lost momentum in the Brazilian economy, negatively affecting economic, employment and income growth. The collapse of the Brazilian economic model of the 2000s again highlights the importance of examining the factors that determine increases in productivity. ${ }^{6}$ In this debate, it is accepted that industry plays an incontrovertible role (Messa, 2015), both because it is more capital-intensive and because it is an important source of innovation and is able to generate better quality jobs, higher remuneration and lower employee turnover, promoting the development of specialized human capital. Cavalcante, Jacinto and De Negri (2015) stress the importance of increasing the productivity of the Brazilian economy in order to return to the cycle of economic growth. In that connection, they identify investment in R\&D and innovation as drivers of future labour productivity. In the same paper, they test the hypothesis that labour productivity in less technology-intensive sectors is more sensitive to the acquisition of machinery and equipment than to investment in R\&D, and find results that confirm this theory.

Just as the innovation process is influenced to a large extent by its local dimension, over the years the knowledge absorption capacity of Brazilian industry has tended to be more influenced by factors related to proximity. It can therefore be inferred that companies in specialized regions tend to spend more on machinery and equipment and on training their workforces, in search of better productive practices, while the performance of companies in diversified regions depends on their capacity to take advantage of the benefits of the diversity of a localized space which, in addition to offering a larger supply of skilled labour, promotes innovative activity related to the R\&D process.

In this study, the determinants of the knowledge absorption capacity of the Brazilian processing industry are estimated based on PINTEC microdata. The analysis was carried out for all the companies included in PINTEC in 2008, 2011 and 2014, and takes into account companies' internal and municipal determinants, ranking them byfirm and municipality. The chosen period was one of major national productive restructuring, marked by the repercussions of the international crisis of 2008.

\section{Database and methodology}

The empirical analysis entailed combining different databases. The main databases used were PINTEC and the PIA-Enterprise, both overseen by IBGE, and the Annual Social Information Report (RAIS) of the Ministry of Economy. Given that the first two databases are organized using the National Register of Legal Entities (CNPJ) to identify companies, a database was created in which the observation unit is the enterprise-local unit and the RAIS data are aggregated at the municipal level. In accordance with the frequency of PINTEC, the analysis was performed for 2008, 2011 and 2014. The empirical analysis was carried out with microdata from PINTEC and PIA-Enterprise that is difficult to access owing to the confidentiality of the information.

\section{Methodology}

The analysis of Brazilian industrial companies' investment in innovative activities reveals the importance of considering the environment in which they operate. Assuming that this is also a determinant of their trajectories, the empirical analysis therefore takes into account controls for the effects of the municipality. A decision was therefore made to use a multilevel model. This decision was based on the characteristics that the analysis assumes are related to interaction with the environment in which companies operate, with a possible mutual causality relationship between individuals (in this case companies) and the environment. This interrelation cannot be ignored in the analysis (Goldstein, 1995). The possibility of a

6 Rising commodity prices, capital inflows, expanding consumption, low savings rates, among other factors. 
relationship between the variability of individual characteristics determined by the environment in which the firms operate must be considered in the analysis, because, although there is a control for individual and environmental characteristics, there is the possibility that - since no distinction is made between the hierarchical levels and their correlation - the estimates are spurious. With this approach to the analysis, with companies included in different groups, it must be assumed that their characteristics are not entirely independent of the environment and that there may be groups that, on average, have a more or less determining impact on certain characteristics of the companies.

The simplest model of hierarchical analysis is random effects analysis of variance. This initial specification captures the differences between the overall mean of the response variable and the specific mean of each second-level group. It is represented as follows (Raudenbush and Bryk, 2002):

$$
\begin{gathered}
Y_{i j}=\beta_{0 j}+r_{i j} \\
\beta_{0 j}=\gamma_{00}+u_{0 j} \\
\gamma_{i j}=\gamma_{00}+u_{0 j}+r_{i j}
\end{gathered}
$$

where $Y_{i j}=$ dependent variable for each individual $i$ in a group $j ; \beta_{0 j}=$ mean of the dependent variable for each group $j ; r_{i j}=$ error term of individual $i$ in group $j$ (normally distributed with mean 0 and variance $\sigma^{2}$ ); $\gamma_{00}=$ population mean of the dependent variable; and $u_{0 j}=$ random effect of group $j$ (or deviation of group $j$ from the population mean), with a normal distribution of $u_{0 j}$. The variance of the response variable is given by:

$$
\operatorname{Var}\left(Y_{i j}=\operatorname{Var}\left(u_{0 j}+r_{i j}\right)=\tau_{00}+\sigma^{2}\right.
$$

Variance decomposition ( $\tau_{00}$ - between groups and $\sigma^{2}$ - within groups) allows the intraclass correlation coefficient (ICC) to be calculated, indicating the portion of total variance that is explained by the second hierarchical level, that is to say the extent to which the environment determines individual behaviour. The ICC is represented by:

$$
\rho=\tau_{00} /\left(\tau_{00}+\sigma^{2}\right)
$$

Applying a generic multilevel analysis model to the analysis of absorptive capacity (AC), the following is obtained: ${ }^{7}$

$$
A C_{i j}=\beta_{0 j}+\beta_{1 j}\left(\text { level }_{i j}\right)+r_{i j} \text {, }
$$

with:

$$
\begin{gathered}
\beta_{0 j}=\gamma_{00}+\gamma_{01}\left(2 \text { level }_{j}\right)+u_{0 j} \\
\beta_{1 j}=\gamma_{10}
\end{gathered}
$$

Adapting the proposal of Cohen and Levinthal (1990) to the specificities of PINTEC, including explanatory variables for the labour market and urban structure, the determinants of expenditure on creating absorptive capacity are measured. The "absorptive capacity" variable was constructed using the variables for a company's innovative activity. In PINTEC these are: internal R\&D, acquisition of external $R \& D$, acquisition of other external knowledge, acquisition of software, acquisition of machinery and equipment, and training. ${ }^{8}$ According to Araújo and Salerno (2015), it is possible to group innovative activities into two distinct factors: "R\&D-driven innovation", which is highly correlated with internal and external R\&D, and "machinery- and training-driven innovation", correlated with the acquisition of

\footnotetext{
7 Neither interaction between first and second level variables nor randomization of the slope were included, so the specification of $\beta_{1 j}$ is simpler.

8 Although investments in "Introduction of technological innovations into the market" and "Other preparations for production and distribution" are also innovative activities according to PINTEC (IBGE, n/d), these two forms of investment were not included because they do not relate to either of the two dimensions of innovation examined and presented in this paper.
} 
machinery and equipment and training. ${ }^{9}$ Based on Araújo and Salerno (2015), innovative activities are divided into two groups. The first group is intended to represent a type of absorptive capacity that is closer to Cohen and Levinthal's (1990) original concept, which is highly correlated with expenditure on internal or external R\&D - responsible for generating the capabilities that favour recognition, assimilation and application of external information in firms' internal routines. The second group, presented as a possible alternative to economies that lag behind in economic and industrial development, is related to investment in machinery and equipment and training, which allows the generated knowledge to be absorbed and incorporated into more modern machinery and equipment, assuming that such investments tend to be made to increase production efficiency.

Based on the idea of activities that are "R\&D-driven" and "machinery- and training- driven", two distinct groups of innovative activities were formed:

- The sum of the amounts spent on internal R\&D, the acquisition of external R\&D and the acquisition of other knowledge, defined as "AC-product"; 10 and

- The sum of the amounts spent on acquiring software, machinery and equipment and on training, defined as "AC-process".

The first group represents a form of absorptive capacity that is more conducive to developing new products and the second group is intended to correlate with the possibility of innovation in production processes.

Having defined how the dependent variables were constructed, a strategy needed to be formulated to enable analysis of the effects of investments on knowledge absorption capacity from a territorial perspective. It was required because the PINTEC data are not disaggregated to a point that would allow for assessment of the influence of the territory (in this case, the municipality). ${ }^{11}$ To this end, two strategies were established that involved aggregating PINTEC data with company location information, using the "Unidade Local" (local unit) section of the Annual Industrial Survey -Enterprise (PIA-UL), based on National Register of Legal Entities entries for each company. The first strategy was to use companies with PIA-UL data that had only one local unit, excluding the others, and the second strategy was to generate a second database by dividing PINTEC (National Registry of Legal Entities) values among the different local units that were in the same Register. ${ }^{12}$ The next section presents the results of the econometric estimation for the two strategies.

Table 1 shows the variables used in the empirical exercises and the two hierarchical levels considered in the analysis. The table also includes a short description of each of the variables. ${ }^{13}$

The goal of estimation of absorptive capacity, differentiating between absorption that favours product innovation and absorption that favours process innovation, is to verify possible differences between these two forms of absorption, controlling for company characteristics and observing how they differ in terms of the territorial-level determinants, to identify the relationships between different urban structures and knowledge absorption activities.

9 Araújo and Salerno (2015) performed a factor analysis of the innovative activities in PINTEC 2008 and obtained two factors that condense their importance: one that is highly correlated with intramural and external R\&D, which they call "R\&D-driven innovation", and another that is highly correlated with the acquisition of machinery and equipment and training, which they call "machinery- and training-driven innovation".

${ }^{10}$ The variables were deflated using the industrial wholesale price index (IPA-indústria) at 2008 prices, and a log transformation (In) was performed.

11 The only territorial breakdown of PINTEC is the unit of the federation (IBGE, $n / d$ ).

12 The information present in PIA-UL did not allow for better determination of the local units that were responsible for expenditure or where the R\&D professionals were assigned, among other data collected by PINTEC, so a simple division was performed, whereby each local unit received the same portion of the expenditure.

13 The indicators of occupational technological hierarchy were constructed according to Rodrigues, Oliveira and Albuquerque (2007) and the indicators of sectoral technological intensity were constructed according to Cavalcante (2014). 
Table 1

Description of the variables used in the empirical analysis

\begin{tabular}{|c|c|c|}
\hline Variable name & Indicator & Construction of the variable \\
\hline \multicolumn{3}{|l|}{ First level: company characteristics } \\
\hline Net revenue & Scale of production & Ln of net sales revenue recorded in the company's balance sheet \\
\hline Ongoing R\&D & Technological opportunity & Dummy variable for companies that reported ongoing R\&D \\
\hline Maintain market & \multirow[t]{2}{*}{ Degree of appropriability } & $\begin{array}{l}\text { Dummy variable for companies that considered it very important } \\
\text { to innovate in order to maintain their market share }\end{array}$ \\
\hline Expand market & & $\begin{array}{l}\text { Dummy variable for companies that considered it very important } \\
\text { to innovate in order to expand their market share }\end{array}$ \\
\hline Cooperation agreement & Cooperation to innovate & $\begin{array}{l}\text { Dummy variable for companies that participated in cooperation } \\
\text { agreements with other organizations }\end{array}$ \\
\hline Doctors - working exclusively & \multirow[t]{2}{*}{ Profile of workforce in R\&D } & \multirow{2}{*}{$\begin{array}{l}\text { Number of staff with masters or doctorate degrees working } \\
\text { exclusively on R\&D }\end{array}$} \\
\hline Masters - working exclusively & & \\
\hline $\begin{array}{l}\text { National Classification of Economic Activities, } \\
\text { version 2.0 (CNAE 2.0) - Division }\end{array}$ & Industrial sector control & Dummy variables for the 24 industrial sectors - process industry \\
\hline \multicolumn{3}{|l|}{ Second level: municipal characteristics } \\
\hline Industrial diversification & \multirow[t]{3}{*}{ Urbanization indicators } & $\begin{array}{l}\text { Industrial diversification index (modified } \\
\text { Herfindahl-Hirschmann Index) }\end{array}$ \\
\hline Distance from São Paulo & & Distance from the city of São Paulo, measured in hours \\
\hline Location quotient - production services & & $\begin{array}{l}\text { Location quotient (LQ) for production services (Annual Social } \\
\text { Information Report (RAIS)) }\end{array}$ \\
\hline Location quotient - low intensity & \multirow{4}{*}{$\begin{array}{l}\text { Indicators of production } \\
\text { specialization }\end{array}$} & $\begin{array}{l}\text { Location quotient (LQ) for industries with low } \\
\text { technology-intensity (RAIS) }\end{array}$ \\
\hline Location quotient - lower-moderate intensity & & $\begin{array}{l}\text { Location quotient (LQ) for industries with lower-moderate } \\
\text { technology-intensity (RAIS) }\end{array}$ \\
\hline Location quotient - upper-moderate intensity & & $\begin{array}{l}\text { Location quotient (LQ) for industries with upper-moderate } \\
\text { technology-intensity (RAIS) }\end{array}$ \\
\hline Location quotient - high intensity & & $\begin{array}{l}\text { Location quotient (LQ) for industries with high technology- } \\
\text { intensity (RAIS) }\end{array}$ \\
\hline Employment - upper-senior & \multirow[t]{6}{*}{ Labour market indicators } & $\begin{array}{l}\text { Employee participation in "upper-senior" technology hierarchy } \\
\text { positions (RAIS) }\end{array}$ \\
\hline Employment - lower-senior & & $\begin{array}{l}\text { Employee participation in "lower-senior" technology hierarchy } \\
\text { positions (RAIS) }\end{array}$ \\
\hline Employment - middle-senior & & $\begin{array}{l}\text { Employee participation in "middle-senior" technology hierarchy } \\
\text { positions (RAIS) }\end{array}$ \\
\hline Education - full higher education & & $\begin{array}{l}\text { Participation in the industry by employees with full higher } \\
\text { education (RAIS) }\end{array}$ \\
\hline Education - master's degree & & $\begin{array}{l}\text { Participation in the industry by employees } \\
\text { with master's degrees (RAIS) }\end{array}$ \\
\hline Education - doctorate & & Participation in the industry by employees with doctorates (RAIS) \\
\hline \multicolumn{3}{|l|}{ Regional and year controls } \\
\hline North & \multirow{5}{*}{$\begin{array}{l}\text { Dummy variables for controls } \\
\text { for regional characteristics }\end{array}$} & Dummy variable North \\
\hline North-East & & Dummy variable North-East \\
\hline South-East & & Dummy variable South-East - state of São Paulo was omitted \\
\hline Central-West & & Dummy variable Central-West \\
\hline South & & Dummy variable South \\
\hline 2011 & \multirow{2}{*}{$\begin{array}{l}\text { Dummy variables for } 2011 \\
\text { and } 2014-2008 \text { omitted }\end{array}$} & Dummy variable for 2011 \\
\hline 2014 & & Dummy variable for 2014 \\
\hline
\end{tabular}

Source: Prepared by the authors.

The following hypotheses are tested: that the most R\&D-intensive innovative activities - which also therefore create knowledge absorption capacity that is conducive to product innovation - are strongly correlated with production diversification (Jacobs, 1969; Duranton and Puga, 2001; Storper and Venables, 2004; Araújo, 2014, among others) and with the most technology-intensive sectors (Henderson, Kuncoro and Turner, 1995; Araújo, 2014, among others), and that innovative activities that are more intensive in machinery, equipment and training - generating, therefore, the capacity to absorb knowledge that is conducive to process innovation - show greater correlation with industrial specialization and with sectors that are less technology-intensive (Duranton and Puga, 2001; Barbour and Markusen, 2007; among others). 


\section{Analysis of the results}

The results relating to the two empirical strategies adopted are presented and discussed below, with estimates that take into account only companies with a single "local unit", which did not bias the territorial perspective but did mean excluding a significant portion of the companies, ${ }^{14}$ and estimates that take into account all the companies in PINTEC, dividing the amounts spent on innovative activities among the different local units, as mentioned above, with the resulting bias in the territorial perspective.

\section{Absorptive capacity and product innovation}

The results presented in this section contribute to the discussion surrounding which company and municipality characteristics are most favourable for investment in innovative activities that resulted in capabilities to recognize, assimilate and use existing or available know-how in the innovation process (AC-product).

The first step in structuring the hierarchical model was estimation of the unconditional model (analysis of variance), to determine the proportion of the model's total variance that is explained at the first and second levels, thus measuring the influence of the environment (municipality) on individual behaviour (company). Having outlined this initial specification, table 2 presents the results of the estimation of indicators for companies (first level) and for the general model, also including municipal controls.

The analysis of variance estimate justifies the use of the hierarchical model, the intraclass correlation coefficient is significant at $1 \%$ and the municipalities account for $4.02 \%$ and $4.42 \%$ of the variance in the data, for the two databases. As expected, the inclusion of first-level explanatory variables reduces the municipal share of total variance in the data and the variance remains significant.

In the estimation of first-level determinants, the results are as expected for the two groups of companies: an increase in net revenue (company size) increases expenditure on "AC-product"; companies that reported ongoing R\&D spend more than other companies; companies that considered it very important to innovate in order to maintain or expand their market shares spend more than other companies; companies that were parties to cooperation agreements to perform innovative activities spend more than others; an increase in staff with master's degrees or doctorates working exclusively on R\&D increases expenditure on "AC-product". In the case of the last of these results, there is a marked difference in magnitude between the two estimations: the result for "single local units" is significantly higher than that for "division of amounts between local units". This suggests there may be a limitation on the empirical strategy of dividing amounts equally among local units. Also at the company level, sector dummy variables (National Classification of Economic Activities, version 2.0 (CNAE 2.0)-Division) and dummy variables for 2011 and 2014 were included, showing that in 2011 expenditure was lower than in 2008 and that in 2014 it was higher.

The aim of including second-level variables in the general model was to filter all possible companyand territory-level impacts that might be responsible for determining investment in absorptive capacity for product development. The results for the first-level variables were significant and as expected, as in the previous specifications. The results were also maintained for sector controls and for the dummy year variables. Overall, despite some changes in the statistical significance of the control coefficients for municipal characteristics and a change in the sign of the full higher education variable, the results of the estimations of determinants of expenditure on "AC-product" are supported by theory.

\footnotetext{
14 It can be assumed that larger companies were excluded from this analysis.
} 


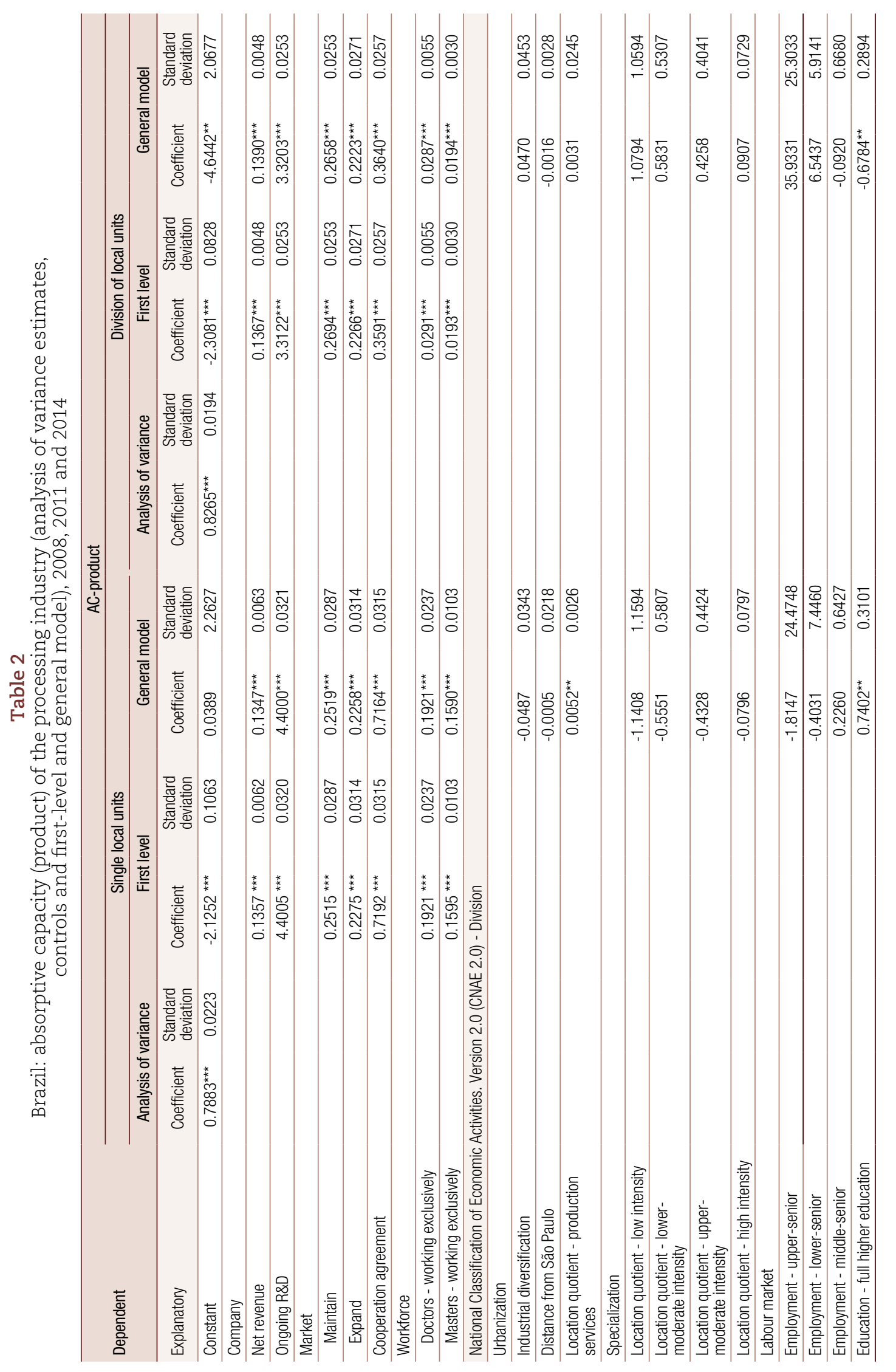




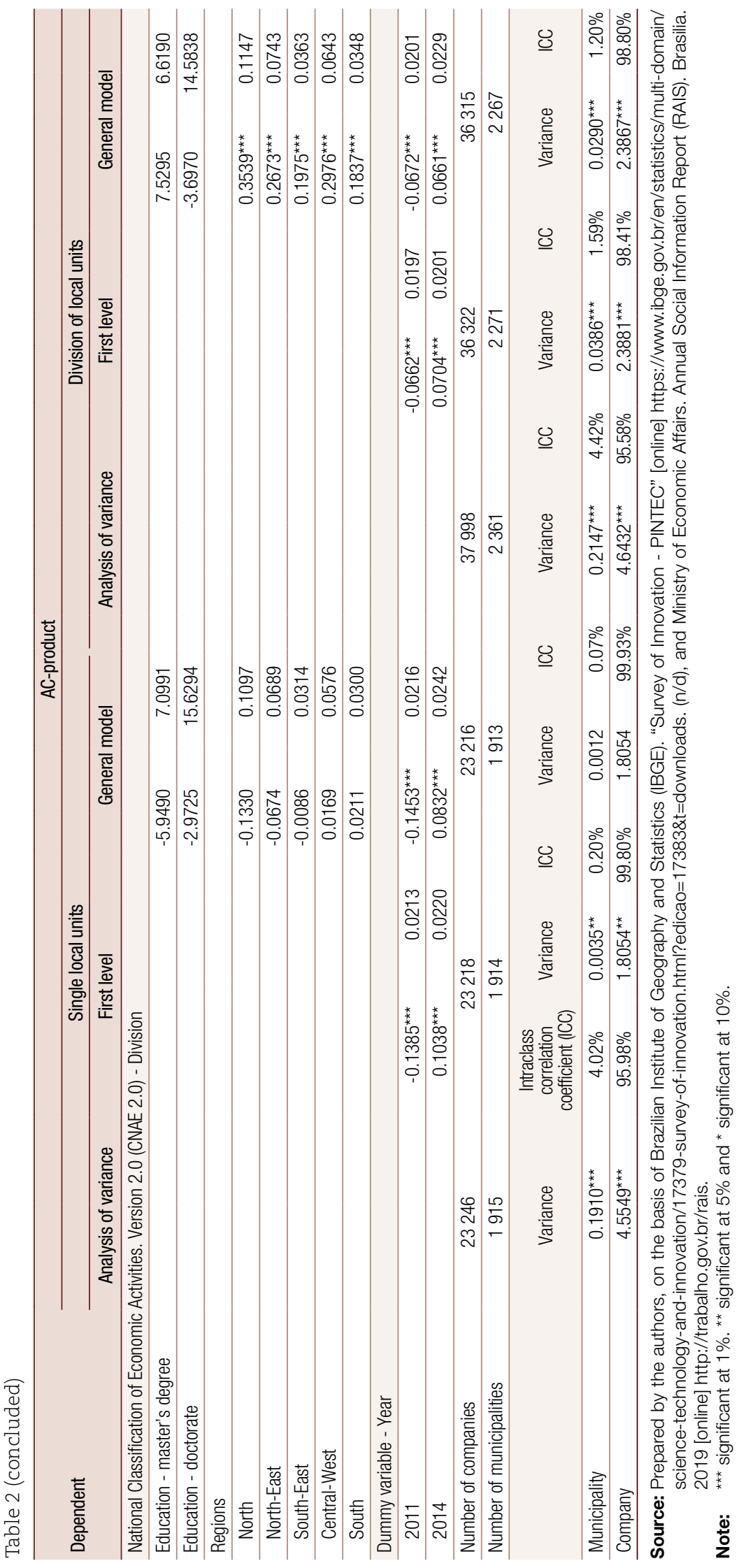


As expected, the controls for the urbanization variables were not significant in this general specification. The intention with these controls was to verify the localization effects when determining knowledge absorption capacity expenditure, testing the hypotheses of Jacobs (1969) and Marshall (1890) and the literature on the outcomes of these two original proposals for expenditure on innovative R\&D activities. There was expected to be positive correlation between municipal determinants of "AC-product" expenditure and urbanization, production diversification and the most technology-intensive sectors, but this was not observed. Only the production services variable for the "single local unit" model was significant, at $5 \%$. The controls for production specialization were not significant in either estimate.

The only municipal control that was significant (at 5\%) was the municipal proportion of employees with full higher education in the industry. However, this result has different signs for the two groups of companies analysed. In the estimation that divided expenditure among firms' local units, the results suggest that an increase in the proportion of employees with full higher education in municipalities decreases expenditure on "AC-product". This can be explained by the greater territorial dispersion of employees with full higher education, as opposed to the spatial concentration of expenditure on R\&D-related activities, in addition to the greater growth in the proportion of employees with full higher education in the least technology-intensive sectors, which are also less intensive in such expenditure. In addition, companies with "single local units" appear to have been able to take advantage of this space, with greater expenditure on these innovative activities in the municipalities with a larger proportion of such workers.

\section{Absorptive capacity and process innovation}

Applying procedures that are similar to those used in the previous section, the results presented here feed into the discussion of the characteristics that are conducive to investment in absorption of external knowledge, from the perspective that backward economies have the option of absorbing production knowledge by acquiring better production inputs, machinery and equipment, and by training their labour forces. These investments tend to generate production improvements by enabling new ways of doing things and thus potentially resulting in process innovations. Companies' internal factors and locational factors that determine expenses are evaluated in what we have called "AC-process" in this study. The expected result is of less dependence on spatial effects related to urbanization (proximity to São Paulo, available production services and industrial diversification) and greater dependence on specialized spaces (industrial location quotients (LQ)) and on factors that contribute to lower labour costs (Puga and Venables, 1996; Duranton and Puga, 2001; Duranton and Puga, 2005; Barbour and Markusen, 2007; among others).

The first finding from table 3 is that there is a lower intraclass correlation coefficient than in the analysis of variance model that measured the determinants of R\&D-related investments. This suggests that, as expected, R\&D-related activities and investments are more sensitive to territorial factors than expenditure on machinery, equipment and training. 


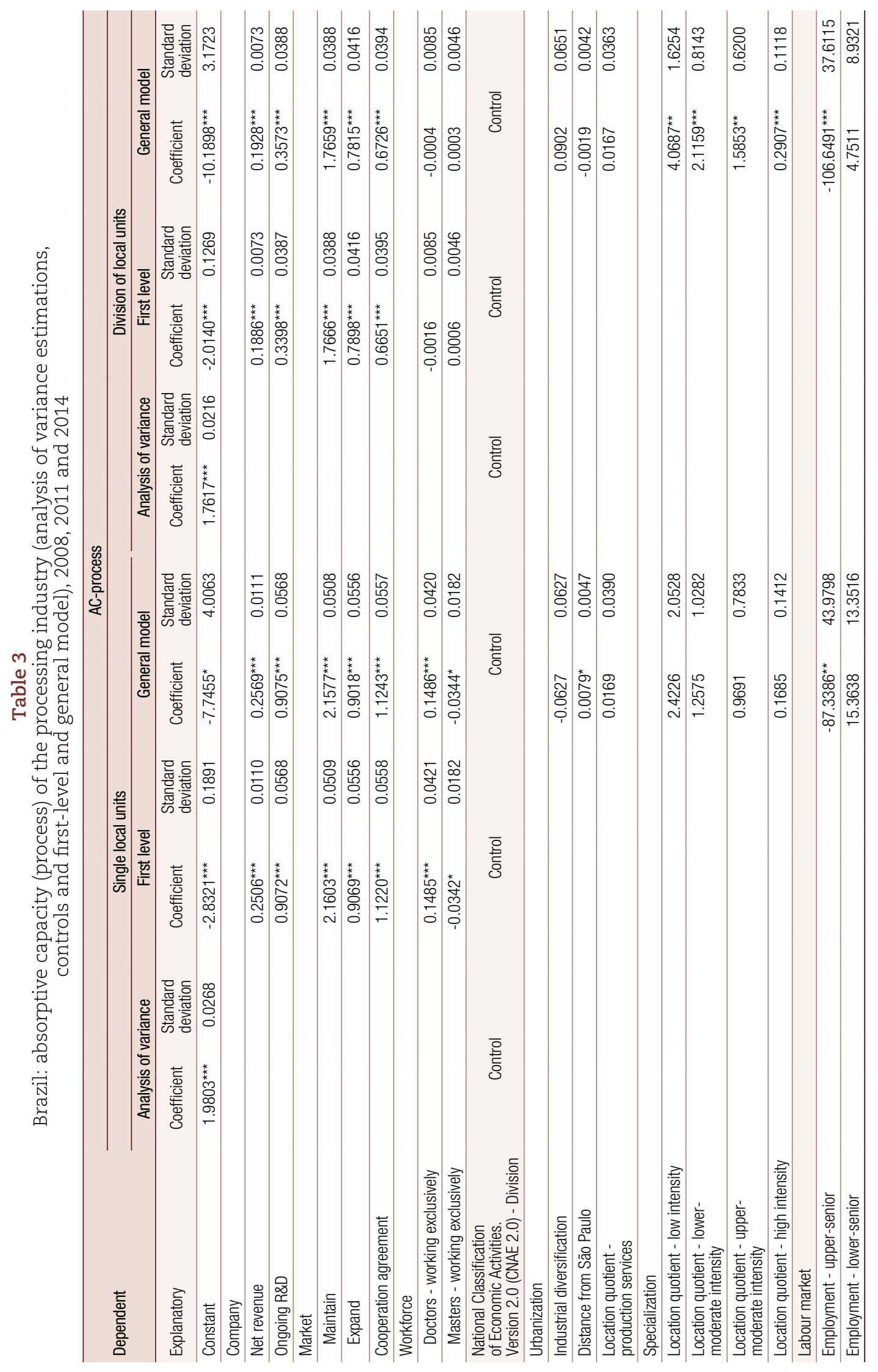




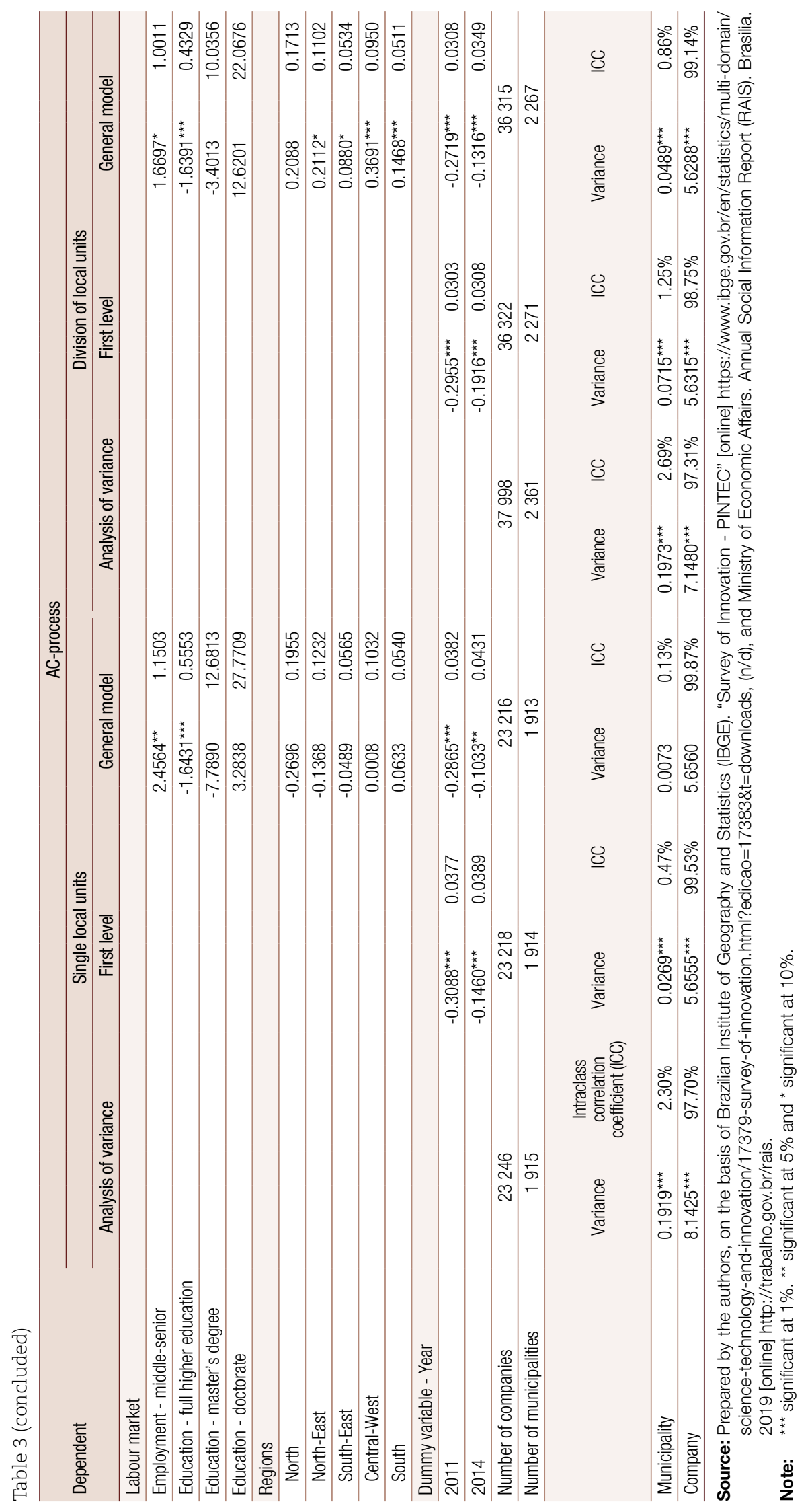


Growth in net revenues has greater positive influence on expenditure on "AC-process" than on "AC-product", with a positive and significant relationship in both cases; greater importance - significant at $1 \%$ - is attached to innovative investments as a strategy to expand or maintain market share when determining "AC-process" expenditure than when determining "AC-product" expenditure; ongoing $R \& D$ has a positive effect on "AC-process" expenditure, but its influence on "AC-product" is greater; participation in cooperation agreements with other organizations increases "AC-process" expenditure; the presence of staff with master's degrees and doctorates was not shown to significantly influence "AC-process" expenditure in the analysis where expenditure was divided between local units, while it significantly affected such expenditure in the analysis by "single local units". In this case, the number of staff with doctorates working exclusively on R\&D increases "AC-process" expenditure and the number of staff with master's degrees reduces such expenditure. The dummy variables for 2011 and 2014 show that this expenditure declined following the international crisis of 2008, although the impact was greater in 2011 than in 2014. With the inclusion of first-level variables, the intraclass correlation coefficient decreases but remains significant at $1 \%$.

The results of the general model are consistent with those obtained previously and the first-level controls maintain their signs, with significances and magnitudes that are similar to the first-level only estimates. In the general model, a reduction in "AC-process" expenditure was observed when there was growth in the municipal proportion of workers in upper-senior hierarchical positions and a reduction was observed when there was growth in the proportion of workers with full higher education. Both these factors are linked to the municipal profile of industrial workers and increases in labour costs. Larger proportions of workers in middle-senior positions of the technological hierarchy in municipalities had a positive influence on such expenditure by Brazilian industrial companies.

Concerning localization controls, differences in the results are observed when comparing the two groups of companies ("single local units" and "all companies, with amounts divided between local units"). For the first group, the "specialization" controls were not significant; therefore, there was no major influence from this "space" on increases in "AC-process" expenditure, as expected. Another expected result for this group of companies is a rise in expenditure as the distance from the municipality of São Paulo increases, suggesting a relationship with dispersive factors (Von Thünen, 1966). When the analysis is extended to all of PINTEC, adapting its reality to the goal of this article, the locational specialization factors are within the range that would be expected based on theory, with influence from this space on growth in expenditure. ${ }^{15}$ This influence grows as the technological intensity of the sector decreases. In this second estimation exercise, the distance from São Paulo declined in significance.

The company determinants of expenditure on absorptive capacity showed the expected signs and significances. The proxy for technological opportunities was the presence of ongoing R\&D, based on the understanding that companies located in economic sectors with major opportunities need to be constantly connected to production and scientific advances (Cohen and Levinthal, 1990; Klevorick and others, 1995; Albuquerque, 1998; among others). The possibility of benefiting from the results of expenditure on innovative activities was defined as an appropriability condition (Nelson and Winter, 1982; Cohen and Levinthal, 1990; Albuquerque, 1998; among others). The existence of such conditions would strengthen the strategy of companies to invest in innovation. The proxy used assumes that the results of the innovative process enabled maintenance or expansion of market share, suggesting the existence of favourable returns on the innovative process. Once again, the observed sign was as expected. The results confirmed the positive influence of cooperation agreements for innovation on development of absorptive capacities, as highlighted by Vega-Jurado, Gutiérrez-Gracia and Fernández-de-Lucio (2008).

15 Not disaggregated at the municipal level. 


\section{Conclusions}

This article contributes to the literature on this topic by measuring the determinants of investment in absorptive capacity by Brazilian industrial firms, taking into account the importance of territorial determinants. Overall, the results obtained from the econometric exercises are supported by theory, with internal company determinants of "AC-product" and "AC-process" showing the expected signs and significances.

In the case of territorial determinants, greater correlation was expected between R\&D and urban attributes (production diversification, specialization in production services and proximity to the city of São Paulo); this was not supported by the results (Jacobs, 1969; Duranton and Puga, 2000; Storper and Venables, 2004; among others). This can be explained by Brazil's weakness in developing more efficient and voluminous expenditure on these activities. This would explain the lag in the Brazilian economy, suggesting that increasing spending would have a significant impact at the national level, improving productivity and market shares, albeit with progress initially limited to reaching a domestic market.

As expected, the results for "AC-process" indicate that specialized spaces are the main "destinations" for expenditure on machinery and equipment, training and software (for the results where expenditures were divided among local units). Duranton and Puga (2001) had already drawn attention to the possibility that, despite being very favourable to R\&D activities, diversified urban spaces hinder expansion of production activity, so that specialized spaces become preferable, offering localization/MAR ${ }^{16}$ externalities without the high costs that diversified urban spaces entail. Also, as expected and as observed in the results, the increase in the influence of specialization on expenditure as technological intensity decreases is explained by the fact that the lower the intensity, the lower the production complexity and productivity. Lower production complexity means less capacity to cover the costs of this "localized space" and, as it demands fewer urban attributes, production ultimately becomes located in specialized spaces. Another factor that reinforces this movement, and which was also observed in the empirical exercises relates to labour costs (Puga and Venables, 1996).

Although the results are satisfactory in that they are in line with the theories on which the analysis was based, the results concerning urban attributes may have been influenced by the limitations of PINTEC with regard to territorial analysis. The two strategies implemented to overcome these limitations entailed either excluding firms with more than one local unit ${ }^{17}$ or distributing expenditure on innovative activities among local units arbitrarily, as there was no alternative within PIA-UL that would have allowed for a better indication of the municipality of the expenditure. However, identification of these problems, combined with the results, reaffirms the importance of further analysis of how the environments in which companies operate influence the innovation process. PINTEC, the main national database on the characteristics of the innovation process, limits such progress. These problems would be avoidable if the database indicated the municipality of the expenditure on innovative activities, among other data that would enable evaluation of the Brazilian innovative process from a territorial perspective. As explained, evaluation of the Brazilian innovation process from a purely sectorial perspective overlooks important factors related to territory and localization-related externalities.

\footnotetext{
${ }^{16}$ Marshall-Arrow-Romer externalities (Combes, 2000).

17 Larger and (because of the characteristics of the innovative process) more innovative companies were probably excluded.
} 


\section{Bibliography}

Abramovitz, M. (1986), "Catching up, forging ahead, and falling behind", The Journal of Economic History, vol. 46, No. 2, June.

Albuquerque, E. (1998), "Patentes segundo a abordagem neo-schumpeteriana: uma discussão introdutória", Brazilian Journal of Political Economy, vol. 18, No. 4.

Araújo, B. and M. Salerno (2015), "Technological strategies and learning-by-exporting: the case of Brazilian manufacturing firms, 2006-2008", International Business Review, vol. 24, No. 5, October.

Araújo, V. (2014), "Dimensão local da inovação no Brasil: determinantes e efeitos de proximidade", doctoral thesis, São Paulo, University of São Paulo.

Barbour, E. and A. Markusen (2007), "Regional occupational and industrial structure: does one imply the other?", International Regional Science Review, vol. 30, No. 1, January, SAGE.

Bell, M. and K. Pavitt (1997), "Technological accumulation and industrial growth: contrasts between developed and developing countries", Technology, Globalisation and Economic Performance, D. Archibugi and J. Michie (eds.), Cambridge, Cambridge University Press.

Cavalcante, L. (2014), "Classificações tecnológicas: uma sistematização", Nota Técnica, No. 17, Brasilia, Institute of Applied Economic Research (IPEA), March.

Cavalcante, L., P. Jacinto and F. De Negri (2015), "P\&D, Inovação e produtividade na indústria brasileira", Produtividade no Brasil: desempenho e determinantes. Volume 2 - Determinantes, F. De Negri and L. Cavalcante (coords.), Brasilia, Brazilian Industrial Development Agency (ABDI)/Institute of Applied Economic Research (IPEA).

Chiarini, T. (2014), "Transferência internacional da tecnologia: interpretações e reflexões: o caso brasileiro no paradigma das TICs na última década do século XX e no alvorecer do século XXI", doctoral thesis, Campinas, State University at Campinas (UNICAMP).

Cohen, W. and D. Levinthal (1990), "Absorptive capacity: a new perspective on learning and innovation", Administrative Science Quarterly, vol. 35, No. 1, March.

(1989), "Innovation and learning: the two faces of R \& D", The Economic Journal, vol. 99, No. 397, September.

Combes, P. (2000), "Marshall-Arrow-Romer externalities and city growth", CERAS working paper, No. 99-06, January.

De Negri, F. (2006), "Determinantes da capacidade de absorção das firmas brasileiras: qual a influência do perfil da mão-de-obra?", Tecnologia, exportação e emprego, J. De Negri, F. De Negri and D. Coelho (coords.), Brasilia, Institute of Applied Economic Research (IPEA).

Duranton, G. and D. Puga (2005), "From sectoral to functional urban specialisation", Journal of Urban Economics, vol. 57, No. 2, March.

(2001), "Nursery cities: urban diversity, process innovation, and the life cycle of products", American Economic Review, vol. 91, No. 5.

(2000), "Diversity and specialisation in cities: why, where and when does it matter?", Urban Studies, vol. 37, No. 3, SAGE, March.

Ernst, D. and L. Kim (2002), "Global production networks, knowledge diffusion, and local capability formation", Research Policy, vol. 31, No. 8-9, December.

Fajnzylber, F. (1990), "Industrialization in Latin America: from the 'black box' to the 'empty box'”, Cuadernos de la CEPAL, No. 60 (LC/G.1534/Rev.1-P), Santiago, Economic Commission for Latin America and the Caribbean (ECLAC), August.

Feldman, M. (1994), The Geography of Innovation, Boston, Kluwer Academic Publishers.

Fontes, G., R. Simões and A. Oliveira (2010), "Urban attributes and wage disparities in Brazil: a multilevel hierarchical model", Regional Studies, vol. 44, No. 5.

Freitas, E. (2012), "Economias externas, atributos urbanos e produtividade: evidências a partir do nível salarial industrial das microrregiões brasileiras, 2000-2010", master's thesis, Belo Horizonte, Federal University of Minas Gerais (UFMG).

Galinari, R., M. Lemos and P. Amaral (2006), "Retornos crescentes urbanos: a influência do espaço na diferenciação da taxa salarial no Brasil”, Tecnologia, exportação e emprego, J. De Negri, F. De Negri and D. Coelho (coords.), Brasilia, Institute of Applied Economic Research (IPEA).

Glaeser, E. and others (1992), "Growth in cities", Journal of Political Economy, vol. 100, No. 6, December. Goldstein, H. (1995), Multilevel Statistical Models, London, Edward Arnold.

Henderson, J. (2003), "Marshall's scale economies", Journal of Urban Economics, vol. 53, No. 1, January.

Henderson, J., A. Kuncoro and M. Turner (1995), "Industrial development in cities", Journal of Political Economy, vol. 103, No. 5. 
IBGE (Brazilian Institute of Geography and Statistics) (2017), "Pesquisa Industrial Anual - Empresa - PIAEmpresa" [online] https://sidra.ibge.gov.br/pesquisa/pia-empresa/quadros/brasil/2017.

(n/d), "Pesquisa de Inovação - PINTEC" [online] https://www.ibge.gov.br/estatisticas/multidominio/cienciatecnologia-e-inovacao/9141-pesquisa-de-inovacao.html?edicao=9142\&t=downloads.

Jacobs, J. (1969), The Economy of Cities, New York, Random House.

Kaldor, N. (1957), "A model of economic growth", The Economic Journal, vol. 57, No. 268, December.

Kim, L. and R. Nelson (2000), Technology, Learning and Innovation: experiences of Newly Industrializing Economies, Cambridge, Cambridge University Press.

Klevorick, A. and others (1995), "On the sources and significance of interindustry differences in technological opportunities", Research Policy, vol. 24, No. 2, March.

Malerba, F. (1992), "Learning by firms and incremental technical change", The Economic Journal, vol. 102, No. 413, July.

Marshall, A. (1890), Principles of Economics, vol. I, New York, Macmillan and Co.

McCombie, J. and P. Thirlwall (1994), Economic Growth and the Balance-of- Payments Constraint, New York, St. Martin's Press.

Merhav, M. (1969), Technological Dependence, Monopoly and Growth, London, Pergamon Press.

Messa, A. (2015), "Determinantes da produtividade na indústria brasileira", Produtividade no Brasil: desempenho e determinantes. Volume 2 - Determinantes, F. De Negri and L. Cavalcante (coords.), Brasilia, Brazilian Industrial Development Agency (ABDI)/Institute of Applied Economic Research (IPEA).

Meyer-Krahmer, F. and U. Schmoch (1998), "Science-based technologies: university-industry interactions in four fields", Research Policy, vol. 27, No. 8, December.

Ministry of Economic Affairs (2019), Relação Anual de Informações Sociais (RAIS), Brasilia [online] http:// trabalho.gov.br/rais.

Nelson, R, and S. Winter (1982), An Evolutionary Theory of Economic Change, Cambridge, The Belknap Press.

Puga, D. and A. Venables (1996), "The spread of industry: spatial agglomeration in economic development", Discussion Paper, No. 279, Centre for Economic Performance (CEP).

Raudenbush, S. and A. Bryk (2002), Hierarchical Linear Models: Applications and Data Analysis Methods, Thousand Oaks, SAGE Publications.

Rodrigues, E., A. de Oliveira and E. Albuquerque (2007), "Uma análise da mobilidade ocupacional no Brasil segundo o nível tecnológico das ocupações" [online] http://www.abep.org.br/publicacoes/index.php/ anais/article/view/1888/1846.

Rosa, A. (2013), "Capacidade absortiva de empresas que possuem interação com universidades", master's tesis, São Leopoldo, University do Vale do Rio dos Sinos (UNISINOS).

Rosenberg, N. (1983), Inside the Black Box: Technology and Economics, Cambridge, Cambridge University Press.

Schumpeter, J. (1982), A teoria do desenvolvimento econômico, Os economistas, São Paulo, Abril Cultural.

Storper, M. and A. Venables (2004), "Buzz: face-to-face contact and the urban economy", Journal of Economic Geography, vol. 4, No. 4, August.

Tavares, M. (2016), "The growth and decline of import substitution in Brazil", ECLAC Thinking: Selected Texts (1948-1998) (LC/G.26699), Santiago, Economic Commission for Latin America and the Caribbean (ECLAC)/Fondo de Cultura Económica (FCE).

Teece, D. and G. Pisano (1994), "The dynamic capabilities of firms: an introduction", Industrial and Corporate Change, vol. 3, No. 3, September.

Teece, D., G. Pisano and A. Shuen (1997), "Dynamic capabilities and strategic management", Strategic Management Journal, vol. 18, No. 7, August.

Thirlwall, P. (1979), "The balance of payments constraint as an explanation of international growth rate differences", Banca Nazionale del Lavoro Quarterly Review, vol. 32, No. 138, Rome, Banca Nazionale del Lavoro.

Van den Bosch, F., H. Volberda and M. de Boer (1999), "Coevolution of firm absorptive capacity and knowledge environment: organizational forms and combinative capabilities", Organization Science, vol. 10, No. 5.

Vega-Jurado, J., A. Gutiérrez-Gracia and I. Fernández-de-Lucio (2008), "Analyzing the determinants of firm's absorptive capacity: beyond R\&D", R\&D Management, vol. 38, No. 4, September.

Von Thünen, J. (1966), Von Thünen's Isolated State: An English Edition of Der Isolierte Staat, P. Hall (ed.), Oxford, Pergamon Press.

Zahra, S. and G. George (2002), "Absorptive capacity: a review, reconceptualization, and extension", The Academy of Management Review, vol. 27, No. 2, April. 